staff roster, now 3,500, has declined by less than that. The director, Alexander Glodeanu, asks, "How can anyone ask me to fire a physicist who will not know how to set up a company or to work at anything less specialized?"

Even so, science at the institute is looking up. Its microproduction centre, founded to manufacture one-off pieces of equipment otherwise available only in the West, has been closed down. Instead, the institute has taken on projects newly recognized to be important, such as the environmental impact of tritium contamination from nuclear power stations. It has also developed a range of collaborations with scientists in the West, often through European Union projects. But, despite the evident inefficiency, the Institute of Atomic Physics is a shining example to the other applied science institutes.

That is one reason why Palade, the research minister, is trying to orchestrate the return of some industrial research units to industry. But, given the threeyear delay in starting on this task, it is now not as simple as it might have been, he says. Some of the industry centres' research units have set themselves up as independent contract research companies. Some have disappeared. However, there have been some successes this year.

For example, Avera, a very large company manufacturing pumping equipment, has taken back a research and development unit, as has the major hydroelectric power company Resita. "We expect these trends to continue", says Palade, "but the problem is that the mother company needs to be very strong, while our industry is generally weak."

As reforms drag slowly on, scientists are getting used to the freedom of postCeaussescu life. The dictator's fear of science and technology had bizarre consequences, now frequently recalled for amusement. How can you explain without despair, for example, that the president of a large country, with a strong cultural tradition, so hated computers that it was forbidden even to use the word on television? Or that the word 'fossil' was similarly banned, in case audiences were tempted to make derogatory references about the ageing Ceaussescu?

The situation sounds ludicrously comical now, but scientists remember yet more vividly the atmosphere of fear in which they had to work. "We always had to be careful how we spoke, because you never knew who was an informer", says Valeriu Zoran, a research director at the Institute of Physics in Bucharest. Scientists no longer have to keep looking over their shoulders.

Another benefit is the freedom to travel abroad. But that remains an abstract freedom. Few can find the funds to travel.

Alison Abbott

\title{
Uncontrolled university boom
}

Bucharest. Universities in Romania suffered the usual fate in communist countries: they lost their independence and they lost their research base.

After 1948, the universities were purged and many staff were sent to jail. Many others left the country. Many courses, particularly in the humanities, were stopped and subjects such as journalism transferred to communist party schools. Research institutes attached to universities were transferred to the Romanian Academy.

According to its rector, Emil Constantinescu, the University of Bucharest suffered more than any because it was Romania's prime cultural symbol. It was founded 130 years ago, on the site of the College of Royal Studies, which was itself established in 1694.

Now a member of parliament as well as being president of the Romanian Rectors Conference, Constantinescu has been the main force behind the postcommunist reform of the university system.

There was no witchhunt of university staff after the revolution, he says, but nonetheless many lost their jobs. The students played the biggest role in choosing who stayed. Parallel courses were set up, and some professors whose courses did not attract enough students were asked to leave. Others were offered the chance to improve.

But those who left did not find themselves without a job. There was a very curious phenomenon in the years following the revolution. The increased demand for student places meant that student numbers in all state higher education institutes rose from 7,000 in 1990 to 30,000 in 1992 , and that was still not enough.

Further demand was met by the establishment of private universities which started to spring up everywhere. It is estimated that there are over 60 such institutes, enrolling possibly 100,000 students.

Using makeshift premises - a cinema during the day or a secondary school during the evening, for example - these private universities are staffed partly by former state university professors and partly by academics with full-time jobs, either at state universities or institutes of the Romanian Academy, who need to top up their meagre incomes.

The flourishing of these private univer- sities is almost an accident. It has been made possible by a law passed in 1990 that legalized private higher education institutes. The government had hoped the result would be private tutoring for university entrance, forbidden in Ceauşescu's day. The outcome was not predicted, and is potentially disastrous for Romanian education standards.

Though not accredited, the private universities claim to issue degrees. Many offer courses very similar to those offered in state universities, others offer unconventional subjects such as homeopathy. Most are also extremely ambitious, offering programmes in popular and expensive subjects such as medicine or architecture. Inevitably, the quality of the courses is very questionable. "They are a real problem," says Constantinescu, "because the consumer interest is not protected." But things may soon change; Romania's new accreditation committee is busily assessing the suitability of all institutes to offer recognized degrees. A new law also allows students at private universities to sit their final examinations at a state university if they prefer.

Within the state system, the universities have since 1990 been busy reconstructing their curricula, introducing courses in the humanities, Western languages and business studies. They have also been striving to reintroduce research. Twenty-five research centres have been set up in association with departments at the University of Bucharest. Links with research institutes of the Romanian academy are being forged, and $\mathrm{PhD}$ programmes being introduced.

These changes are being conducted with a dramatically shrinking budget. The 1992-93 budget of US\$92 million was 30 per cent lower than in the previous year and the downward trend continues.

A further strain on the system arises because a large proportion of teaching staff were promoted after the revolution. That is meant as compensation for yet another bizarre peculiarity of the Ceausescu years. As one means of suppressing the academic community, Ceauşescu saw to it that there were no promotions for academics after 1974.

Inevitably, there was a clamour for restitution after 1990. A generation of academics held at the lowest pay-scales for most of their careers wanted promotion immediately. Viriligiu Constantinescu, president of the Romanian Academy, who was rector of the Polytechnic of Bucharest from 1990 to 1992 , says that he tried unsuccessfully to ask for patience, warning academics that promotions should depend on a proper assessment of performance. But there proved no way of controlling the demand. 